\title{
Innovation Management in Swedish Municipalities
}

\section{Thomas Wihlman, Magnus Hoppe, Ulla Wihlman, Hélène Sandmark}

\begin{abstract}
Research on public sector innovation is still limited, and increased knowledge of innovation processes is needed. This article is a based on a study of the implementation of innovation policies in Swedish municipalities, and gives a first-hand, empirical view of some of the complexities of innovation in the public sector. The study took place in four municipalities in central Sweden. The municipalities varied in size and organisational forms. Interviews and policy documents were used for data collection.The results showed that the innovation policies were not followed by action, which may be described as not mobilizing dynamic capabilities to create innovativeness. Thus, dynamic capabilities, such as learning and HRM, Human Resource Management, were not used in conjunction with innovation. Particularly amongst senior management there was a negative attitude towards the innovative capacity of their organization. Middle management saw possibilities. However, barriers such as extensive control systems removed the focus from innovation. There was a lack of communication between senior management and middle management regarding innovation. The conclusion was that innovation, as both concept and practice, was not fully embraced by the municipalities.

It is suggested that generative leadership, opening up communication within the organisations, especially between employees, could be beneficial, and that a common understanding and definition of the innovation concept is needed. Integration of top-down processes with bottom-up processes, such as employee-driven innovation, is also suggested.
\end{abstract}

Keywords: Public sector, innovation, innovation capacity, dynamic capabilities, innovation concept, management, barriers, opportunities, employee-driven innovation, thematic analysis, summative content analysis 


\section{Introduction}

The interest in public sector innovation, such as the use of new methods and technology and new forms of service output, is increasing. Individualisation of services, limited economic resources, demographic change (e.g., an aging population demanding more care), and social problems are seen as requiring innovation and the implementation of an innovative culture in the public sector (Davila, Epstein \& Shelton 2005; Bason 2010; Bekkers, Edelenbos \& Steijn 2011; Harris \& Albury 2009). Attention has been given to how e.g. public procurement can be used to stimulate innovations at providers (Edquist \& Zabala-Iturriagagoitia 2012; Knutsson $\&$ Thomasson 2014), thus in practice outsourcing public sector innovation to other actors (Wihlman, Sandmark \& Hoppe 2013). Less attention has been given to the innovativeness of the public organisation, how the public sector can be innovative in itself, where, according to Bommert (2010), research is limited.

Lumpkin and Gregory (1996) offer a description where innovativeness stands for an organisation's willingness, tendency and ability to engage in and support new ideas, novelties, experimentation and creative processes that may result in innovations. Although deregulation, freedom of choice among service providers, and new forms of management, influenced by New Public Management (NPM), have transformed the public sector in recent decades (Christensen \& Lægreid 2007; Hasselbladh, Bejerot, \& Gustafsson 2008), it has not led to increased innovativeness (Hartman 2011). The hoped for effects in making the public organisation more adaptable to today's needs has not been reached (Lindberg, Czarniawska \& Solli 2015; Hood 2011). There share this view with the OECD, who are critical of Swedish innovation policy as it "misses the dynamics and potential benefits of innovation in the public sector and society more widely" (OECD 2013, 32).

\section{Objectives and outline of the article}

Research into public sector innovation has increased in recent years (Grødem 2014; Matthews, Lewis \& Cook 2009) but knowledge gaps remain, and there is a particular lack of empirical research (Bloch \& Bugge 2013; Bommert 2010). Also, knowledge of innovation methods and support for what works in fostering public sector innovation, and innovativeness is not extensive. Thus our aim was to study the implementation of municipal innovation policies, within the realm of two research questions:

1. What were the attitudes of managers towards innovation?

2. How did public sector managers describe their actions to implement innovation policies?

The study takes as its starting points policy documents, and also includes interviews with five senior managers and six middle managers.

All municipalities studied had, in policies (in the article we will use policies as the name of both strategies, policies, visions etcetera), stressed the importance of innovation and innovativeness in the organisations. These policies had been processed at the highest political and management level. Thus, this is the objective for management to achieve.

It should also be noted that this article describes a study, which is part of a larger study with its focus on employee-driven innovation in welfare services. Therefore, our research questions, the analysis, and conclusions in particular include such innovations and the relation of these to management. 
The article is organized as follows: At first we introduce the innovation concept itself, then the notion of dynamic capabilities and employee-driven innovation (EDI). The concept of innovation and EDI relates to the attitudes of the management. The management's views on the organisation's dynamic capabilities, and the use thereof, mainly relates to the management's actions. After the description of the methods used, the results are described. Finally, the findings and their relations to theories and our research questions are discussed. We also make some suggestions for further research.

\section{The innovation concept in a public sector context}

As innovation is fairly new to the public sector, so are the definitions of innovation in the context and also what is needed to promote innovation capabilities. Yet, research has identified several enablers for public sector innovation, such as support from the top, resources for innovation, encouraging staff to innovate, involvement of end-users, attention to the views of all stakeholders, and change and risk management (Borins 2001; Mulgan \& Albury 2003). Also, barriers have been identified. Albury (2005) suggests a framework that includes barriers such as short-term budgets and planning horizons, inadequate skills in active risk or change management, culture of risk aversion, delivery pressures, and administrative burdens.

Besides enablers and barriers to public service innovation, the definition of innovation within a public sector frame seems problematic. Nählinder (2007) stresses the need for conceptual development, noting that we need to consider whether innovation as a concept is applicable to the public sector at all, and also noting (2013) that managers in a municipality studied perceived the concept in different ways. Osborne and Strokosh (2013) as well as Fogelberg, Eriksson and Nählinder (2015) emphasise the need for the double translation of innovation, that is from the private sector to the public sector and from products to services.

Langergaard and Hansen (2013) suggest that, if the concept of innovation should be used within the public sector, it needs to be adapted to the practices and the particular goals of the sector. Such definitions could be those that expand on previous innovation definitions, mostly relating to the private sector, with specific concepts from the public sector, including policy innovation (Windrum \& García-Goñi 2008) and democracy innovation (Bason 2010). However, Langergaard and Hansen (2013) also note that these add-ons do not challenge the present innovation theory. They suggest that an all-encompassing innovation concept must be generic, such as "change that aims at improvement" $(2013,8)$, which then should be the base of innovation definitions and adapted to the particular sector. Consequently, in this study we adopted the following definition of innovation: "The intentional introduction and application within a role, group or organisation of ideas, processes, products or procedures, new to the relevant unit of adoption, designed to significantly benefit the individual, the group, the organization or wider society" (West \& Farr 1990, 9). In practical terms, innovation in this study refers to major changes in processes, service output, technology, the introduction of new methods for welfare services etc. Intentionally, issues and processes of a purely political nature were excluded from our study, as this formally was out of scope for management. That it is not to say that management may not be influential in such cases. 


\section{The use of dynamic capabilities}

An organisational culture where innovation is in focus is highly dependent on the ability to renew (Martins \& Terblanche 2003), constituting the innovativeness of the organisation. The renewal may also be described as using dynamic capabilities, e.g. "the ability to integrate, build and reconfigure internal and external competences to address rapidly changing environments" (Teece, Pisano \& Shuen 1997). Ellström (2010) notes that support for learning, and an understanding of both implicit and explicit work processe,s constitute the basis of innovation. Smith et al. (2012) emphasise that innovation connected to learning should be the focus of human resource management, HRM. Dynamic sharing of knowledge and experience is thus essential for organisations eager to change and improve their innovative capability. If subsystems, such as in this case HRM and economic steering, are used to support innovativeness, this indicates the organisation's commitment to innovation (Glynn 1996) and also the willingness to use dynamic capabilities.

Llewellyn and Tappin (2003) suggest that dynamic capabilities are particularly relevant to the public sector, because the sector focuses on internal resources rather than competitive market behaviour. However, the concept of dynamic capabilities has received little attention in the field of public management (Piening 2013). Piening also suggests that the dynamic capability perspective can enhance our limited understanding of how public organisations change in response to their increasingly turbulent and complex environments. Nisula (2012) argues that the public sector traditionally has fewer dynamic capabilities. There may also be conflicting goals, making renewal challenging (Fernandez \& Rainey 2006; Osborne \& Brown 2005; Piening 2011).

\section{Innovation management and employee-driven innovation}

Management in the public sector faces a different challenge regarding change compared with management in businesses. Swedish public sector managers' leadership is also highly complex, leading to a high turnover of executives (Cregård \& Solli 2008). Compared with private sector managers, public sector managers are often responsible for larger units (Wallin, Pousette \& Dellve 2014; Höckertin 2007) and are affected not only by their own superiors but also by the political process, which governs both the sector and the organisation. Borins (2002) argues that if the political leadership has a trusting relationship with the administration, this will encourage bottom-up innovation as well as appropriate crisis response and agency turnarounds; if not, bottom-up innovation, such as EDI, will be stifled. Complexity has also increased due to the effects of NPM, including increased competition between publicly financed providers; for example, school principals in Sweden must handle new functions such as marketing (Kallstenius 2010). As the manager's role in Swedish municipalities is already highly complex, innovation represents an add-on to this.

Surie and Hazy (2006) advocate a generative leadership that creates the necessary conditions that nurture innovation through connectivity and interaction, that is, a communicative culture, rather than focusing on creativity and individual traits. This may also be seen as a democratic dialogue, as described by Gustavsen (2015). The communicative culture may also be particularly useful in situations where communication between users and employees is important, i.e. situations that may lead to user-driven or employee-driven innovation. Having both management and employees learn methods for communication has also proven successful in fostering idea generation (Åteg et al. 2009). 
In a general perspective, the municipalities, especially their welfare services, are organisations with many employees. In many respects, they may be seen as service organisations, with the meeting with the customer (or client/user) in focus. Such meetings and relations are also at the core of EDI (Klitmøller, Lauring \& Rind Christensen 2007). Another argument for the importance of EDI is that employees have exclusively procedural information about processes (Høyrup 2010). Consequently we use the following definition of EDI by Klitmøller et al (2007): the development and implementation of new organisational forms, service concepts, modes of operation, and service processes in which the ideas, knowledge, time, and creativity of employees are actively used.

Smith et al. (2012) propose that the most relevant factors promoting EDI are management support, autonomy, collaboration, and organisational norms favoring exploration. Saari et al. argue (2015) that it is possible to combine this process with a top-down perspective that includes strategic reflexivity. This also highlights the role of central managers bridging activities such as networks, mediating tools and communication arenas (ibid). Thus the attitudes of management, the use of dynamic capabilities, and the role of the employees are important for the innovation capacity in municipalities.

\section{Methods}

\section{Data collection}

Data was collected from four Swedish municipalities that differed in size and organisational form. They were situated in central Sweden.

Data from the municipalities were collected in two steps. The first part was data collected from 53 strategic documents (Table 1), as a background for the interviews. The local governments were asked to present their main strategic documents, such as operational plans, long-term plans, HRM and salary policies, and innovation strategies, for both the local government as a whole and the units included in this study. Documents were also obtained through the web pages of the municipalities. The documents form the background to questions regarding actions and attitudes, as our overarching aim was to study the fulfillment of innovation policies as described in the documents. Therefore, it was necessary to analyse the contents of the policy documents.

In the second step, semi-structured interviews (Table 2) with 11 managers were performed. Five of the eleven interviews were performed with senior management at three of the four municipalities. All senior managers belonged to top management. Six interviews with middle management were conducted; at a day-care centre, a palliative care unit, a nutrition unit/restaurant, a street/park maintenance unit, a unit for short-term eldercare and a support recruitment center for the elderly and for people with physical or mental disorders. All units were strategically chosen for being different organisational parts of the municipal welfare services, this creating a variety. The units had 10 to 55 employees each. A middle manager subordinated to a district manager, or the equivalent, led each unit. 


\begin{tabular}{|c|c|c|c|}
\hline Municipality & $\begin{array}{l}\text { Documents } \\
\text { identified }\end{array}$ & $\begin{array}{l}\text { Documents } \\
\text { mentioning } \\
\text { innovation }\end{array}$ & $\begin{array}{l}\text { Organisational form in the } \\
\text { municipalities }\end{array}$ \\
\hline $\begin{array}{l}\text { Municipality } \\
\text { A }\end{array}$ & 25 & 18 & $\begin{array}{l}\text { Unified organisation, no division } \\
\text { between purchaser and producer }\end{array}$ \\
\hline $\begin{array}{l}\text { Municipality } \\
\text { B }\end{array}$ & 12 & 6 & $\begin{array}{l}\text { Purchaser-provider organisation, } \\
\text { limited separation between the } \\
\text { functions }\end{array}$ \\
\hline $\begin{array}{l}\text { Municipality } \\
\text { C }\end{array}$ & 6 & 4 & Purchaser-provider organisation \\
\hline $\begin{array}{l}\text { Municipality } \\
\text { D }\end{array}$ & 10 & 1 & Purchaser-provider organisation \\
\hline TOTAL & 53 & 29 & \\
\hline
\end{tabular}

Table 1 Overview of the municipalities and documents used in the analysis

\begin{tabular}{|c|c|c|c|c|}
\hline $\begin{array}{l}\text { Organisational } \\
\text { level }\end{array}$ & $\begin{array}{l}\text { Number } \\
\text { informants }\end{array}$ & $\begin{array}{l}\text { Number } \\
\text { municipalities }\end{array}$ & $\begin{array}{l}\text { Sex, } \\
\text { M/F }\end{array}$ & Age \\
\hline Senior management & 5 & 3 & $3 / 2$ & $\begin{array}{l}40- \\
65\end{array}$ \\
\hline Middle management & 6 & 4 & $1 / 5$ & $\begin{array}{l}35- \\
60\end{array}$ \\
\hline TOTAL & 11 & 4 & $4 / 7$ & $\begin{array}{l}35- \\
65\end{array}$ \\
\hline
\end{tabular}

Table 2 Overview of the informants

Semi-structured interviews with managers were held at each manager's offices and were performed by the first author (TW) from June 2011 to January 2013. Interviews were based on a thematic interview guide. Open-ended questions were asked about the innovation concept, innovation processes, support for innovation, strategies, whether and how innovation questions were discussed in the organisation. Also, questions regarding how management acted in relation to subordinates, learning and innovation, barriers to and opportunities for innovation, and the role of human resource strategies and the HR department regarding innovation related issues were asked. All interviews except one were recorded and transcribed. The unrecorded interview was arranged at short notice. For practical reasons, notes were taken instead. In one of the municipalities, no one from senior management was willing to undertake an interview within the stipulated time frame, thus (Table 2) three municipalities took part here. However, the results of the analysis were discussed with two senior managers from that municipality in separate conversations. They agreed that the analysis reflected a fair picture also of their municipality, as they experienced it. 
Analysis of data

In the document analysis, the official view of innovation was explored by a summative content analysis, as described by Hsieh and Shannon (2005). It was studied how frequently the concept of innovation was used and in which contexts innovation was seen as advantageous, how it was described, and whether particular innovation goals had been set.

A qualitative thematic analysis (Braun \& Clarke 2006) of the interview transcriptions was conducted to sort and code the data, in order to get a deeper understanding of the perceptions of managers. The thematic analysis of the dataset comprised six steps. The first step entailed familiarising with the data, including transcribing, reading, rereading, and noting initial ideas and findings. In the second step, the initial codes were generated, and in the third step themes were searched for. In step four, the themes were reviewed and related to the coded extracts, in step five themes were defined and labeled according to their contents. Finally, in step six, the results were tabulated according to the themes identified. This was done in an iterative process. The themes were continuously discussed between the co-authors.

\section{Methodological considerations}

The study searched for overall patterns, not being a comparative study of municipalities, and thus the results could be transferable to other municipalities, despite the limitation to four Swedish municipalities.

Lincoln and Guba (1986) state that trustworthiness is an essential factor when judging qualitative research. To enhance trustworthiness and avoid interpretative bias inter-subjective agreement was sought in the analysis, as the emerging themes were continuously discussed among the authors. In addition, quotations were used to illustrate each identified theme, connecting the findings to the original interviews.

In order to counteract the likelihood for informants trying to satisfy the interviewer (Alvesson 2003), the interviewer continuously reframed, repeated and expanded questions as described by May (1991).

\section{Ethical aspects}

The recommendations of the Swedish Research Council's (Vetenskapsrådet (Swedish Research Council) 2012) for studies in the humanities and social sciences were followed for this study. To ensure confidentiality, the quotations have been numbered in the Results section. Also to preserve confidentiality, the origins of the examined documents are not described in detail.

\section{Results}

In the policy documents, Innovation was described in very general terms, and mostly without specific goals. Innovation promotion activities were mainly restricted to formulating and disseminating the policy documents. From the interviews, gaps between management levels were found. Old-fashioned structures and bureaucracy were seen as hindrances to innovation. 


\section{Use of the innovation concept in policy documents}

Our overarching aim was to study the implementation of innovation policies as described in policy documents. The policy was decided upon at the political level or the senior management level, serving as an assignment to managers in the organization. Consequently, it was necessary to analyse the contents of the policy documents. A total of 29 documents, representing all the municipalities, containing innovation in some form, were found. However, there was only one policy document found that explicitly was dedicated to innovation. In all the other cases, innovation was a part of long-term strategic plans, HR policies, budgets, and objectives etcetera. We summarise what we found in the different municipalities in the following table:

\begin{tabular}{|l|l|}
\hline $\begin{array}{l}\text { Municipality } \\
\text { A }\end{array}$ & $\begin{array}{l}\text { Innovation was described as directed toward the internal organisation as well } \\
\text { as externally to support improvement beneficial to citizens, commerce, and } \\
\text { industry. The municipality had a specific innovation strategy document. }\end{array}$ \\
\hline $\begin{array}{l}\text { Municipality } \\
\text { B }\end{array}$ & $\begin{array}{l}\text { Innovation was described as an aim to create a thriving municipality. } \\
\text { Incremental internal innovation, although this term was not used, appeared } \\
\text { occasionally in connection with the improvement of the administration. }\end{array}$ \\
\hline $\begin{array}{l}\text { Municipality } \\
\text { C }\end{array}$ & $\begin{array}{l}\text { Innovation was described as a means of improving the provision of services } \\
\text { but there were also goals for innovation procurement. The external focus was } \\
\text { on creating an innovative society together with universities, commerce, and } \\
\text { industry. }\end{array}$ \\
\hline $\begin{array}{l}\text { Municipality } \\
\text { D }\end{array}$ & $\begin{array}{l}\text { Innovation was described as for municipality } 3 \text { except for innovation } \\
\text { procurement, which was not stressed. }\end{array}$ \\
\hline
\end{tabular}

Table 3Overview of innovation in policy documents

The results showed that innovation was mostly described in very general terms, as something beneficial, useful and valuable. Thus, the documents were not very specific. They described innovation as helping to solve grand problems at the societal level such as unemployment and to improve the effectiveness and services at the municipal organizational level. Formal definitions were not made, except in one case where the business oriented $\mathrm{OECD}^{2}$ definition was referred to. The documents were in most cases produced by the management, but decided upon at the political level.

Regarding the knowledge of the existence of the documents, middle management only occasionally mentioned the policy documents, and when doing this they referred to goal conflicts. They spoke mostly in general terms of the advantages of innovation. Senior management were well aware of the documents and their contents, such as:

" $X$ Municipality shall be characterised by the promotion of knowledge, innovation, and entrepreneurship in all its activities, in particular, the way they affect society and in particular co-operation with others" (D3) ${ }^{3}$.

\footnotetext{
2 OECD (2005) covers only the business sector.

${ }^{3} \mathrm{D \#}=$ Document number, $\mathrm{S \# =Senior}$ Management, M\#=Middle Management
} 
According to the document analysis, the municipal organisation was also seen as a partner in creating the open and responsive city for all of society: "An open and responsive city that has the courage to develop its soul constantly. Here differences, ideas, innovations are affirmed: when people meet new ideas are created" (D8).

Innovation was also addressed directly as a responsibility for the employer who should:

"Provide good conditions in a work environment that promotes innovation and development giving the employees the possibility to perform their tasks in a professional manner" (D8).

Some of the descriptions in the documents were directed towards management and/or employees:

"Through clear mission and focus on results, the Municipal Group creates a modern organisation where the meeting with the client and the user is always at the centre. Good leadership promotes creativity and innovation. Proper communication gives clarity and consensus on the objectives that the organisation aims to achieve. The available resources are used efficiently" (D8.)

According to the documents, three of the four municipalities did not pay attention to employee-driven innovation, but in the fourth municipality this was a rather prominent part, visible also in the major strategic plans.

" $X$ municipality desires proud employees who are given the opportunity to achieve the objectives performing a qualitative and results-oriented work in a work environment that is characterised by openness and "high ceiling", trust, innovation, courage and responsibility" (D9).

Only occasionally the role of innovation was described: "A good innovative approach is expected to lead to a development that contributes to improved results and achievement of the politically determined objectives" (D8).

There were also documents specifying what kind of innovations was sought after, and how innovations should come about, such as social innovations or innovation through procurement.

To conclude, we found documents that were not very specific, and therefore, were not concrete in terms of what action should be taken. As mentioned, it was only in one of the municipalities a specific innovation policy was found. Here, one of the departments in that municipality also had very specific objectives regarding innovation, such as how many innovations were searched for and in what areas.

\section{Results: Bureaucracy and gaps between levels}

Two main themes were identified in the thematic interview analysis: bureaucracy and deeply rooted culture, and gaps between hierarchical levels, describing the differences in view between organisational levels. 


\section{Bureaucratic conditions and deeply rooted culture}

The first theme, bureaucracy and deeply rooted culture, was mainly related to senior management. There was a polarity between the optimistic visions of innovation expressed in the documents and the barriers described by senior management in the interviews. Within this theme, there was an absence of management efforts to realise the policies expressed in the documents.

Senior managers doubted whether their organisation had the ability to create and uphold the appropriate work environment and conditions needed to promote innovation and development, as stated in the documents. The capacities or actions were described in a way that did not match the visions articulated in the documents. This may also be regarded as a gap between rhetoric and reality. Senior management admitted that actions in many cases were lacking and gave numerous explanations for this. One document stated: "We put great emphasis on the challenge posed by traditional structures and on encouraging innovation and original thinking" (D11). Senior management perceived in the interviews that such directions were not possible: "The business model in the public sector is such that it is not advantageous to follow new trails" (S2).

The control systems, often in the form of balanced scorecards, were also frequently mentioned as barriers. Senior and middle managers were dissatisfied with the vast number of goals and measurement of these, which drew attention away from the improvement of matters they regarded as more important. One informant was quite outspoken: "We may have to switch control systems completely" (S3).

The current organisational models, with functions separated from each other, were also problematic, according to senior management. As a consequence, diffusion of learning and knowledge was described as difficult: "We learn about ideas that are interesting, but then we insert them into a structure from the 50s" (S2).

The traditions and leadership styles of the organisation were described as bureaucratic and old-fashioned: "In terms of Tayloristic thinking, the public sector is at the forefront" (S1).

One senior manager viewed his principal task as changing the leadership style for all managers in that municipality, to focus more on relevant goals, not necessarily the current objectives. This was also meant to lead to empowered employees, which could result in innovation. However, this change effort was done in isolation, as further reform efforts toward a more innovative capability were not taken: "We only think we are creating innovation" (S1).

A senior manager also described innovation as just a trend or buzzword: "This is not something new. What was wrong with the old suggestion boxes?" (S5). Another senior manager declared that quality systems were more important than innovation, as they (the staff) were used to work with such systems.

Senior management also expressed concerns about barriers and deficiencies in the communicative culture. This could mean a pervasive attitude in the organisation that employees were not allowed to think that they were very special people coming up with great ideas. Another barrier mentioned was the striving for consensus, also described as conflict avoidance. Taking an innovation from idea to practice may lead to conflict, as something existing is challenged by something new; the potential for conflict can be avoided by just not advancing ideas: "There is considerable skepticism about anything different; there is a strong tradition of managing, but not of renewal” (S4). 


\section{Gaps between hierarchical levels}

The second theme, gaps between hierarchical levels, relates to differences between the management groups in terms of their views of innovation. Senior management described several barriers to innovation. Whereas senior management had a more negative attitude towards opportunities for innovation, middle management perceived and acted upon what they saw as opportunities. Senior management mentioned the difficulty of supporting innovation in action, as opposed to moral support, referring to problems with financing, reward systems, etc.: "Our weakest ability is to organise and find a system that orchestrates the innovation process" (S3).

A more specific difficulty experienced by senior management was the lack of employee time for innovation because of what was described as "optimised" staffing: "Time is a problem because I do not think employees would say that they have time for it" (S3). Middle management also saw difficulties in finding the time necessary for innovation; still incremental innovation was described as taking place, such as new methods to care for the elderly with dementia. Senior management did however, not recognise these incremental innovations as innovations. Also, innovations were not reported systematically, according to middle managers. Consequently, successful or unsuccessful innovations and their financial, quality, and customer satisfaction effects, were not known.

Middle managers described how they encouraged their employees to be innovative, as described by a relatively new manager: "as I now have the status of manager, I can encourage good initiatives. I would like to take the opportunity to encourage people to make fun, exciting things" (M1).

In a few units, the middle manager had encouraged those who wanted to champion innovative ideas, by starting a project. Participation in such projects was seen as an opportunity for employee knowledge development, but sometimes also as a reward. One senior manager dismissed this type of action, seeing it as conflict avoidance where the middle manager did not dare to say no to unfruitful ideas, where the usefulness might be doubted.

A senior manager expressed distrust of middle management: "For some reason, the message of innovation stops at middle management" (S5). There were exceptions, however, when middle managers had the full support of their superiors: "I have made substantial changes to my unit as I want it to be number one in Sweden, and I have the full support for this from both politicians and my boss. The HR department has also helped me with new means of recruitment so that I can achieve my goal” (M3).

One problem for middle management was the dominance of a short-term perspective and a focus on budget and efficiency. Despite how it was described in the policy documents, innovation was experienced as a second-ranked goal. Senior management admitted that there were contradictory messages; innovation was necessary, but short-term goals, primarily financial ones, were even more important. No actions were mentioned as taken in order to solve these conflicts.

Senior management described that the HR strategy was rarely used in the organisation to support innovation. Only wage policies were used to a small extent in this respect. Besides, there was no systemic follow-up of competencies in the organisation and accomplished learning that could be used as a system for continuous learning from experiences.

Innovation promotion activities were restricted mainly to formulating and disseminating policy documents, holding a seminar on innovation, and having discussions at workplace 
meetings. Special funding was not allocated. Nor were process facilitators, experts in innovation, engaged.

In the interviews, middle managers cited examples of innovation occurring in their units, despite the lack of dedicated innovation processes and support from various functions. Such innovations could be additional methods to make elderly people more active, simplified administrative routines, or new ways to inform newly arrived refugees of their rights and obligations.

Middle management argued that innovations such as these were needed, due to increasing competition and demands from the public, politicians, and senior management. Lack of resources and the need to find new ways to work were other driving forces encouraging middle management to promote innovation.

Further differences between senior management and middle management were found in their views on risk. When senior managers were proposing an idea to political leaders, objections such as "is this evidence-based" or "has anyone tried this before" were frequently raised. In connection with the desire "not to waste the taxpayer's money", this recurrent questioning of change initiatives was seen as hindering innovation.

In contrast to senior management, middle management expressed less fear of taking risks with new ideas and methods. Middle managers occasionally discussed development issues with colleagues, but also claimed that they rarely specifically talked about innovation processes and innovations made. In line with this, co-operation with other units, and open innovation system initiatives in which citizens or customers could take part, were also rare. When communicating with other managers, this was mainly done to ask if they had made similar innovations or if the colleagues could see any risk with the implementation of a certain innovation.

Thus, innovation was described in very general terms and actions were restricted to local initiatives. Gaps between management levels were found and old-fashioned structures and bureaucracy were seen as hindrance to innovation.

\section{Discussion}

The results of this study were differences in perspective between the two groups of managers. The senior managers mistrusted the possibilities of implementation of the innovation policies, while the middle managers acted upon the policies in a concrete way. This suggests that the lack of consolidated action for innovation in the municipalities is mainly a senior management problem.

\section{Attitudes towards innovation - barriers but also opportunities}

Innovation policies are difficult to implement, as the findings of this study indicate. The study points to a major barrier, differences in views between managers on different levels. In the documents visions of fostering an innovative culture were formulated; to achieve this as senior management described it, substantial structural and cultural barriers had to be overcome. Middle management also experienced barriers, such as lack of resources, prioritisation of adhering to the budget, and conflicting and sometimes irrelevant goals. However, they also saw innovation, based on the ideas and initiatives of employees, as possible. Depending on the hierarchical level, the perception of what constituted a barrier varied. 
Senior management described barriers, such as organisational traditions, bureaucracy, and lack of efficient control systems and risk aversion. These barriers are well known in research (Albury 2005; Bommert 2010). Senior management even felt that innovation was not happening at all, and some also saw a conflict between innovation and quality systems.

Middle management experienced conflicts between demands for innovation and other organisational goals and demands, but nonetheless found room for incremental innovation. However, as Brandi and Hasse (2012) note, an innovation is not an innovation until it is recognised as such in a particular cultural context. That senior management did not recognise innovations made at the unit level indicates that these innovations were either limited to the unit context or not communicated to other parts of the organisation.

One of few examples of a strategy for implementing innovative working procedures was found at the middle management level. One manager promoted her vision of change in the unit by recruiting employees committed to innovation, early adopters in terms of innovation diffusion (cf. Rogers 2003). Nonetheless, the lack of structured processes and support systems may sometimes have hindered the implementation of new, innovative ideas.

\section{Actions not taken - missing dynamic capabilities}

Senior managers found the policies difficult or even unrealistic to realise. This can also be seen as a missing will to use the existing dynamic capability (Piening 2013), for such a significant change as creating an innovative capacity in municipal organisations), or to extend the dynamic capabilities, for instance in co-operation with external partners.

An important part of the dynamic capability is also learning and support for learning. Learning may be seen as a basis for innovation, as described by Ellström (2010). Smith et al. (2012) emphasise that innovation connected to learning should be the focus of HRM, but this was not the case here. Dynamic sharing of knowledge and experience is thus essential for organisations eager to change and improve their innovative capability. If subsystems, such as in this case HRM and economic steering, support innovation, this would indicate the organisation's commitment to innovation (Glynn 1996) but such a commitment was not found in this study.

It can be argued that, in the public sector, capacities for renewal, dynamic capabilities, and innovation are not particularly important (Shleifer 1998). Citizens demand continuity, transparency, and rule of law when dealing with the authorities. Through elections, the citizens have decided how public services should be run. In addition, according to Swedish law, municipalities also have certain mandatory responsibilities (Regeringen (Government Offices of Sweden) 1991). Thus, municipalities cannot just change their business concept, which some senior managers referred to as necessary if they should be able to create an innovative culture. However, in times of recession, with a rapidly aging population, social problems, demands of a well-educated population for the country to remain competitive, etc., it is hard to dismiss the idea that innovative solutions are needed in the public sector. It can also be argued, as mentioned earlier by Llewellyn and Tappin (2003), that dynamic capabilities are particularly relevant to the public sector. According to this study these capabilities are only used to a limited extent. We may see employees, learning and the capabilities of employees as a resource, leading to EDI, and there were also some examples of this, as reported by middle management. However, EDI was not a part of a strategy to become innovative, and senior management did seldom express the possibilities of EDI. One explanation may be as Stewart $(2014,248)$ describes it: "these (bureaucratic) obstacles manifest themselves as a series of tensions within the host department, in particular, risk aversion may become, in the implementation frame, an ongoing concern with control. This 
was despite the fact that employees are in frequent contact with customers, and face daily challenges in providing the services (Høyrup 2010), a situation very common to the municipalities.

Thus, the implementation of a high innovative capacity fell short due to several barriers, despite good intentions expressed in strategic documents. It did so in three of the four important aspects Brooke Dobni (2008) describes: infrastructure (i.e. the use of the dynamic capabilities), knowledge/attitude about innovation, and an environment and context conducive to innovation. Innovation arises through the interplay of various actors (Dougherty 2004; Fonseca 2004; Tuomi 2002; Zerfass \& Huck 2007), and this interplay was not found in the studied municipalities, something that could have been supported by a generative leadership (Surie \& Hazy 2006). Riivari et al. (2012) underscores the importance of the congruency of management, the ability to have discussions and supportability, as the organisational virtues, which most effectively can enhance organisational innovativeness. Here we may add that the gaps between management levels in this study thus can also be seen in terms of congruency.

It could also be discussed that the uncertainty of what innovation is, i. e. about the concept of innovation and its use within the public sector, could be a major hindrance to using and mobilisation of the dynamic capabilities and the employees as a resource for innovation.

There may be alternative explanations to these failures. One such is to see innovation as a management fad or as a management virus (Røvik 2011), or as one of the magic concepts Pollitt et al. (2011) describes. So if management have a desire to be seen as modern innovation is the word to use. However, innovation was not a part of the everyday habits of the public organisations studied. Collaboration and a unified view on innovation were missing.

Current innovation concepts, from businesses and technology, are difficult to translate into the organisational context of the public sector (Langergaard \& Hansen 2013), which may be a reason for failures here. Thus, there is complexity with service and authority goals as well as the diversity of stakeholders, including politicians. Cregård and Solli (2008) have demonstrated that the relationships between municipal managers and leading politicians are very close, and that, to survive, managers must act in a way that does not jeopardize these fragile relationships. Sørensen and Torfing (2011) note that public innovation should ideally correspond to the preferences of elected politicians. In addition, Todnem By (2005) claims that research into change management often ignores organisational politics and conflict.

In our study the differences between middle and senior management also indicate a lack of communication between them regarding focus, the definition of innovation, and the type of innovation needed, pointing to difficulties in handling the concept of innovation. In studying a Finnish municipality, Nisula (2012), in line with this study, found the most negative attitude towards innovation at top management.

Related to the present findings, and as shown in this study, senior management were skeptical of the dynamic capabilities of the organisation, in line with what Nisula (2012) suggests. Efforts to improve the dynamic capabilities were limited. Only minor management efforts were initiated, despite the vision of innovative capacities. As Llewellyn and Tappin (2003) suggest, dynamic capabilities may be crucial for the public sector. The results obtained in the studied organisations should therefore theoretically lead to limited innovation created, and this was what senior management reported, although some incremental innovation apparently occurred as described by middle management. 


\section{Suggestions for further research}

Based on the results of the study, some suggestions for further research may be proposed. As incremental innovation did occur, despite the lack of proper support, it would be interesting to study what a wholehearted investment in innovation and innovativeness and a clear implementation strategy could achieve. Monitoring such initiatives is likely to deepen our understanding of how public sector organisations can develop their innovative capacity. A hypothesis, well worth studying, may also be rendered; do municipalities fail to create the desired conditions for innovation because different senior managers have different views on the importance and usefulness of innovation and of how to achieve it? Such a study may be worthwhile to undertake also as our results indicated that senior management, in general, did not support efforts to develop innovative ideas or an innovative culture. It may be assumed that new ideas may imply criticism of routines and actions supported or even initiated by management. This could also explain the lack of measures taken to change old structures and working procedures. An alternative explanation could be deficient knowledge of innovation, conflicting perspectives, or insufficient resources to create the necessary amendments. Thus, further studies in this area will be most welcome.

\section{Conclusions}

The results showed a gap between the far-reaching innovation visions and goals, expressed in the documents, and what was actually realised in the use of dynamic capabilities to implement the innovation policies. Senior management, in particular, pointed to barriers, such as bureaucratic traditions. Middle managers had a more sanguine attitude towards innovation, seeing opportunities, including EDI, albeit encumbered by some barriers. The gap between management levels can be explained by their different focuses, and by a lack of communication between them regarding their views and experiences of innovation, but also by the difficulties of adopting the concept of innovation to the municipalities, as well as a lack of understanding of both methods and EDI.

In the studied municipalities, innovation appeared to be an explicit policy, but the implementation of the policy fell short, as the capabilities and resources for change, the dynamic capabilities, were not used. Senior management did not acknowledge the incremental innovations implemented in the units, so the potentials of these limited innovations were not realised. The major barriers to creating an innovative culture, according to the senior managers, were traditions and old structures. Thus innovation, as both concept and practice, was not fully embraced by the municipalities, and in this context had troubles with both attitudes and actions.

We conclude that in this study, little action was taken towards the achievement of policies and goals and thereby increasing innovativeness. We suggest that a lack of communication and an understanding of the innovation concept here was a major hindrance to the implementation of the policies. Our results also indicate that innovation was something not established amongst the senior managers. In other words, innovation in this context had troubles both with attitudes and action. 


\section{References}

Albury David. 2005. "Fostering Innovation in Public Services." Public Money and Management 25 (1): 51-56.

Alvesson Mats. 2003. "Beyond Neopositivists, Romantics, and Localists: A Reflexive Approach to Interviews in Organizational Research." The Academy of Management Review 28 (1): $13-33$.

Åteg M, Wilhelmson L, Backström T, Åberg M.M., Olsson B.K., \& Önnered L. 2009. "Tasks in the Generative Leadership: Creating Conditions for Autonomy and Integration: Researching Work and Learning 6." The 6th International Conference on Researching Work and Learning. http://urn.kb.se/resolve?urn=urn:nbn:se:du-4857.

Bason Christian. 2010. Leading Public Sector Innovation: Co-Creating for a Better Society. Bristol: Policy Press.

Bekker V, Jurian Edelenbos J., \& Bram Steijn B. 2011. Innovation in the Public Sector Linking Capacity and Leadership. Basingstoke: Palgrave-MacMillan.

Bloch C. \& Bugge M.M.. 2013. "Public Sector innovation-From Theory to Measurement." Structural Change and Economic Dynamics 27: 133-45. doi:10.1016/j.strueco.2013.06.008.

Bommert B. 2010. "Collaborative Innovation in the Public Sector." International Public Management Review 11 (1): 15-33.

Borins S. 2001. "Encouraging Innovation in the Public Sector." Journal of Intellectual Capital 2 (3): 310-19.

Borins S.. 2002. "Leadership and Innovation in the Public Sector." Leadership \& Organization Development Journal 23 (8): 467-76.

Brandi U. \& Hasse C. 2012. "Employee-Driven Innovation and Practice-Based Learning in Organizational Cultures.” In , 127-48. Houndmills: Palgrave Macmillan.

Braun V. \& Clarke V.. 2006. "Using Thematic Analysis in Psychology." Qualitative Research in Psychology 3 (2): 77-101. doi:10.1191/1478088706qp063oa.

Brooke Dobni, C. 2008. "Measuring Innovation Culture in Organizations: The Development of a Generalized Innovation Culture Construct Using Exploratory Factor Analysis." European Journal of Innovation Management 11 (4): 539-59. doi:10.1108/14601060810911156.

Christensen T. \& Lægreid P. 2007. Transcending New Public Management: The Transformation of Public Sector Reforms. Burlington: Ashgate.

Cregård A.\& Rolf Solli R.. 2008. “Tango På Toppen - Om Chefsomsättning (Tango at the Top — Executive Turnover)." KFi-Rapport / Kommunforskning I Västsverige, No: 93.

Davila T., Epstein M., \& Shelton R. 2005. The Art of Innovation. Philadelphia, PA: Wharon School Publishing,.

Dougherty D. 2006. "Organizing for Innovation in the 21st Century." The Sage Handbook of Organization Studies 2 (598-617)

Edquist C., \& Zabala-Iturriagagoitia J.M>. 2012. "Public Procurement for Innovation as Mission-Oriented Innovation Policy.” Research Policy 41 (10): 1757-69.

Ellström P-E.. 2010. "Practice-Based Innovation: A Learning Perspective." Journal of Workplace Learning 22 (1/2): 27-40. doi:10.1108/13665621011012834. 
Fernandez S., and Hal G Rainey H.G.. 2006. "Managing Successful Organizational Change in the Public Sector.” Public Administration Review 2006 (March/April): 168-76.

Fogelberg Eriksson A., \& Nählinder J. 2015. "Ledarskap För Innovation i Offentlig Sektor." Helix Working Papers. Linköping: Linköping University.

Fonseca J. 2004. Complexity and Innovation in Organizations. London: Routledge.

Glynn M.A. 1996. "Genius: A Framework Innovative for Relating Individual and Organizational." The Academy of Management Review 21 (4): 1081-1111. doi:10.2307/259165.

Grødem A.S. 2014. "Innovasjon Og Styrning i Bolig Sosialt Arbeid.” Oslo: Institutt for samfunnsforskning.

Gustavsen B. 2015. "Practical Discourse and the Notion of Democratic Dialogue." European Journal of Workplace Innovation 1 (1).

Harris M. \& Albury D. 2009. The Innovation Imperative: Why Radical Innovation Is Needed to Reinvent Public Services for the Recesison and beyond the Recession. 2009. London: Nesta.

Hartman L. ed. 2011. Konkurrensens Konsekvenser: Vad Händer Med Svensk Välfärd (Consequences of Competition: What Happens to the Swedish Welfare). Stockholm: SNS förlag.

Hasselbladh H., Bejerot E., and Gustafsson R.A.. 2008. Bortom New Public Management: Institutionell Transformation I Svensk Sjukvård (Beyond New Public Management: Institutional Transformation in Swedish Healthcare). Lund: Academia adacta. http://www.worldcat.org/title/bortom-new-public-management-institutionell-transformation-isvensk-sjukvard/oclc/228299346.

Höckertin C.. 2007. Organisational Characteristics and Psychosocial Working Conditions in Different Forms of Ownership. Umeå: Umeå Universitet.

Hood C. 2011. "The Ashgate Research Companion to New Public Management - By Tom Christensen and Per Laegreid." Governance 24 (4): 737-39. doi:10.1111/j.14680491.2011.01547_1.x.

Høyrup S.. 2010. "Employee-Driven Innovation and Workplace Learning: Basic Concepts, Approaches and Themes." Transfer: European Review of Labour and Research 16 (2): 14354. doi:10.1177/1024258910364102.

Kallstenius J. 2010. De Mångkulturella Innerstadsskolorna: Om Skolval, Segregation Och Utbildningsstrategier I Stockholm (The Multi-Cultural Inner-City Schools: About the School Selection, Segregation and Educational Strategies in Stockholm). http://urn.kb.se/resolve?urn=urn:nbn:se:su:diva-47149.

Klitmøller A., Lauring J., \& Christensen P.R.. 2007. "Medarbejderdreven Innovation I Den Offentlige Sektor (Employee-Driven Innovation in the Public Sector)." Ledelse \& Erhvervsøkonomi 71 (4): 207-16.

Knutsson H. \& Thomasson A. 2014. "Innovation in the Public Procurement Process: A Study of the Creation of Innovation-Friendly Public Procurement." Public Management Review 16 (2): $242-55$.

Langergaard L.L. \& Hansen A.V. 2013. “Innovation - a One Size Fits All Concept?” The XXIV ISPIM Conference. 
Lincoln Y.S. \& Guba E.G. 1986. Naturalistic Inquiry. Thousand Oaks: Sage Publications Ltd. Lindberg K., Czarniawska B., \& Solli R. . 2015. “After NPM?” Scandinavian Journal of Public Administration 19 (2): 3-6.

Llewellyn S. \& Tappin E. 2003. "Strategy in the Public Sector: Management in the Wilderness." Journal of Management Studies 40 (4): 955-82. doi:10.1111/1467-6486.00366.

Lumpkin G.T. \& and Dess G.G.. 1996. "Clarifying the Entrepreneurial Orientation Construct and Linking It to Performance." Academy of Management Review 21 (1): 135-72.

Martins E C. \& Terblanche F.. 2003. "Building Organisational Culture That Stimulates Creativity and Innovation." European Journal of Innovation Management 6 (1): 64-74. doi:10.1108/14601060310456337.

Matthews M., Lewis C., \& Cook G. 2009. "Public Sector Innovation: A Review of the Literature." Canberra: Australian National Audit Office.

May K.A.. 1991. "Interview Techniques in Qualitative Research: Concerns and Challenges." In , 188-201. Thousand Oaks: Sage Publications.

Mulgan G., \& Albury D.. 2003. Innovation in the Public Sector. U.K. Government.

Nählinder J. 2007. "Innovationer I Offentlig Sektor. En Litteraturöversikt (Innovations in the Public Sector. A Literature Review).”

Nählinder J. 2013. "Understanding Innovation in a Municipal Context: A Conceptual Discussion.” Innovation: Management, Policy and Practice 15 (4): 315-25.

Nisula A-Mm. 2012. "Challenges in Developing Organizational Renewal Capability in the Public Organizations." The 5th ISPIM Innovation Symposium - Stimulating Innovation: Challenges for Management, Science \& Technology.

OECD 2013. "OECD Reviews of Innovation Policy: Sweden 2012.”

Osborne S.P., \& Brown K. 2005. Managing Change and Innovation in Public Service Organizations. Psychology Press. London: Psychology Press.

Osborne S.P. \& Strokosch K. 2013. "It Takes Two to Tango? Understanding the Coproduction of Public Services by Integrating the Services Management and Public Administration Perspectives.” British Journal of Management 24 (S1): S31-47.

Piening E.P. 2011. "Insights into the Process Dynamics of Innovation Implementation: Public Management Review.” Public Management Review 13 (1): 127-127. doi:10.1080/14719037.2010.501615.

Piening E.P. 2013. "Dynamic Capabilities in Public Organizations." Public Management Review 15 (2): 209-45. doi:10.1080/14719037.2012.708358.

Pollitt C., \& Hupe P., 2011. "Talking About Government: The Role of Magic Concepts." Public Management Review 13 (5): 641-58.

Regeringen (Government Offices of Sweden). 1991. Kommunallag (Municipal Law): SFS 1991:900. Stockholm: Government Offices of Sweden.

Riivari E., Lämsä A-M, Kujala J., \& Erika Heiskanen. 2012. "The Ethical Culture of Organisations and Organisational Innovativeness." European Journal of Innovation Management 15 (3): 310-31. doi:10.1108/14601061211243657. 
Rogers E. M. 2003. Diffusion of Innovation, 5th Ed. New York: Free Press.

Røvik K.A.. 2011. "From Fashion to Virus: An Alternative Theory of Organizations' Handling of Management Ideas.” Organization Studies 32 (5): 631-53.

Saari E.., Lehtonen M., \& Toivonen M. 2015. "Making Bottom-up and Top-down Processes Meet in Public Innovation." The Service Industries Journal 35 (6): 325-44.

Shleifer A.. 1998. "State Versus Private Ownership." The Journal of Economic Perspectives 12 (4): 133-50.

Smith A., Courvisanos J., Tuck J., and McEachern S. 2012. "Building the Capacity to Innovate: The Role of Human Capital."

Smith P., Ulhöi J.P. \& Kesting P. 2012. "Mapping Key Antecedents of Employee-Driven Innovations.” Int. J. Human Resources Development and Management 12 (3): 224-36.

Sørensen E. \& Torfing J. 2011. "Enhancing Collaborative Innovation in the Public Sector." Administration \& Society 43: 842-68.

Stewart J. 2014. "Implementing an Innovative Public Sector Program: The Balance between Flexibility and Control.” International Journal of Public Sector Management 27 (3): 241-50.

Surie G. \& Hazy J.K.. 2006. "Generative Leadership: Nurturing Innovation in Complex Systems." E:CO 8 (4): 13-26.

Teece D.J, Pisano G., \& Shuen A. 1997. "Dynamic Capabilities and Strategic Management." Strategic Management Journal 18 (7): 509-33.

Todnem By R. 2005. “Organisational Change Management: A Critical Review.” Journal of Change Management 5 (4): 369-80.

Tuomi I. 2002. Networks of Innovation, Change and Meaning in the Age of Internet. Oxford: Oxford University Press.

Vetenskapsrådet (Swedish Research Council). 2012. Ethical Guidelines for Humanities and Social Sciences. Stockholm: Vetenskapsrådet. http://www.codex.vr.se/en/manniska2. tshml.

Wallin L., Pousette A., \& Dellve L. 2014. "Span of Control and the Significance for Public Sector Managers' Job Demands: A Multilevel Study." Economic and Industrial Democracy 35 (3): 455-81.

West MA, \& Farr J.L.. 1990. Innovation and Creativity at Work: Psychological and Organizational Strategies. Hoboken: John Wiley \& Sons. http://books.google.se/books?id=tqsgAQAAIAAJ.

Wihlman T., Sandmark H., \& Magnus Hoppe M. 2013. "Innovation Policy for Welfare Services in a Swedish Context." Scandinavian Journal of Public Administration 16 (4): 2748.

Windrum P. \& García-Goñi M. 2008. "A Neo-Schumpeterian Model of Health Services Innovation.” Research Policy 37 (4): 649-72.

Zerfass, A., and Huck S. 2007. "Innovation, Communication, and Leadership: New Developments in Strategic Communication." International Journal of Strategic Communication 1 (2): 107-22. doi:10.1080/15531180701298908. 


\section{About the authors:}

Thomas Wihlman,

Ph.D. in Work Life Science, Mälardalen University, Västerås. Independent researcher and consultant; journalist at Swedish magazine Tidningen Kulturen (tidningenkulturen.se).

Sweden

E-mail: wihlman2@gmail.com

Magnus Hoppe

Senior Lecturer Mälardalen University’s Academy for Business, Society and Engineering, Västerås, Sweden; Ph.D. in Business Administration at Åbo Academy

Finland

E-mail: magnus.hoppe@mdh.se

Ulla Wihlman

Ph.D. in Public Health research/Health management at the Nordic School of Public Health in Göteborg. Independent researcher and senior consultant

Sweden

E-mail: ulla.wihlman@gmail.com

Hélène Sandmark

Professor in Public Health Sciences, affiliated to Department of Computer and Systems Sciences at Stockholm University. Ph.D. in Occupational Medicine from Karolinska Institutet in Stockholm

Sweden

E mail: helene.sandmark@dsv.su.se 